\title{
Environmental Hazards and Health Risks Associated with the Use of Mobile Phones
}

\author{
Manivannan Senthil Velmurugan \\ Research Scholar, D.B. Jain College, University of Madras, Chennai, India \\ E-mail:msvelu72@gmail.com
}

Received 19 January 2016; Accepted 30 March 2016;

Publication 2 May 2016

\begin{abstract}
Mobile phones are universally popular due to their convenience. Mobile phones solve problems such as interacting with the people, transfer of data through offering new channels of communication by using a device small enough to fit into one hand. On the other hand, mobile phones may be harmful to the environment and health, and waste disposal issues may be associated with its discharge of radiation. Concerns have been raised recently about the sustainability of mobile phones and its effects on people's health and the environment. The present study discusses the adverse effects associated in using mobile phones, and addresses sustainable perspectives to overcome the same.
\end{abstract}

Keywords: Mobile phone, hazards, environment, health and sustainable.

\section{Introduction}

Mobile phones have become an intrinsic part of most people's lives, connecting them with other people around the world. A mobile phone has several advantages, enabling communication with family, friends, and business wherever a signal is available. In addition, the $3 \mathrm{G}$ telephone enables users to access data; listen to music; play games; send and receive simple text messages known as short message service (SMS); access multimedia messaging services (MMS), voice, and video, as well as internet access

Journal of Green Engineering, Vol. 5, 151-174.

doi: 10.13052/jge1904-4720.524

(C) 2016 River Publishers. All rights reserved. 


\section{M. S. Velmurugan}

through wireless application protocol (WAP). Even though mobile phones have several advantages, there are also significant disadvantages associated with its use. Chemical substances from mobile phones such as arsenic, lithium, cadmium, copper, lead, mercury and zinc are considered toxic. Bereketli et al, (2009), Lincoln et al. (2007) also stated that mobile phones contain a large number of hazardous substances, including antimony, arsenic, beryllium, cadmium, copper, lead, nickel, zinc and this persistent bio accumulative toxins (PBTS), have been associated with cancer and a range of reproductive, neurological, and developmental disorders. When mobiles are discarded, these toxic substances may be released or exposed from decomposing waste in landfills, contaminate the soil and seep into groundwater. Savvilotidou et al. (2014) focused on the determination of the toxic metal content of liquid crystal displays presented in various waste electrical and electronic equipment (WEEE) included mobile phones. Kang et al, (2013) explored that lithium batteries may contribute substantially to environmental pollution, and adverse human health impacts due to potentially toxic materials. Plastics are the leading chemical substance found in mobile phones followed by other miniature materials (Figure 1). Metals build-up in the soil, which can enter the food chain, and in sufficient concentrations may cause health problems. Bharodiya and Kayasth (2012), Lakshmi and Nagan (2010) explained the health hazards of manufacturing components of cell phone along with the

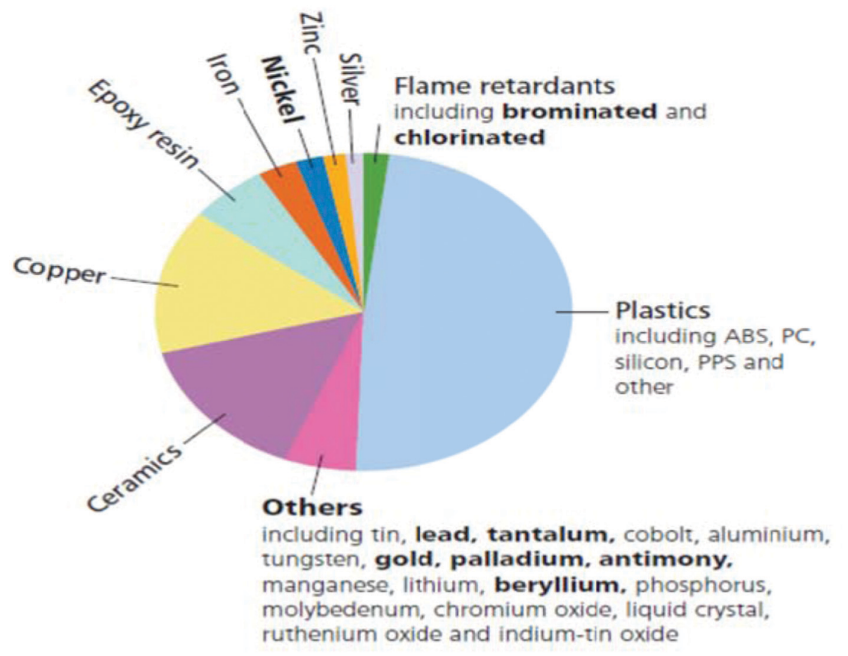

Figure 1 Chemical substances in mobile phones. 
spirit into the lives of individuals. Using mobile phones can harm the brain, and excessive use of mobile phones has been associated with dizziness. The radiations emitted from the phone are also harmful for the eardrum. Furthermore, World Health Organization (WHO, 2013) said that exposure to the radiofrequency (RF) fields emitted by mobile phones are generally 1000 times more than that emitted from base stations, and noted that research had almost exclusively conducted on the possible effects of mobile phones, such as electromagnetic interference, road traffic accidents, cancer and other health-related effects.

Moving towards a more sustainable system of mobile phone production and consumption would help to mitigate or minimize the aforementioned risks associated with mobile phones.

This paper reports the issues related to the use of mobile phones and also focuses on the aspects of sustainability in mobile phones to overcome its adverse effects. The mobile phones could have detrimental effects on people's health and the environment. The major issues related to using mobile phones are as follows:

- Lack of awareness about the health risks.

- Lack of understanding the influence on the environment.

In this paper we will first identify the associated health and environmental risks, and then examine policies and innovation strategies to reduce these risks. The analysis has a survey character, as we derive many insights from the existing literature on the problems and solutions. The literatures of the current research were fallen on mobile phones' risks in regard to energy consumption, environment and health.

\subsection{Energy Consumption}

The production of new mobile phones contribute to the climate change by exhausting energy and virgin materials in processes, thereby releasing greenhouse gases into the atmosphere. The United Nations Environment Programme (Kick the Habit, 2008) estimated that the manufacture of a mobile phone produces about $60 \mathrm{~kg}$ of $\mathrm{CO}_{2 \mathrm{e}}$ and using a mobile phone for a year produces about $122 \mathrm{~kg}$ of $\mathrm{CO}_{2 \mathrm{e}}$. The evaluation of material and energy consumption of mobile phones is an important task in the end-of-life management of electronic products (Yu et al, 2010). The $\mathrm{CO}_{2}$ emissions per subscriber in a year for a $3 \mathrm{G}$ system are equivalent to the emissions from driving a car for $250-380 \mathrm{kms}$ or to 19-21 lts of gasoline (Nokia, 2005). Soonenschein et al. (2009) found that 
energy consumption for the mobile phone call averages $0-5 \mathrm{kWh}$, whereas the washing machine uses about $0-43 \mathrm{kWh}$. Besides, Groupe Speciale Mobile Association (2012) mentioned that if $10 \%$ of the world's mobile phone users turned off their chargers after use, the energy saved in one year could power 60,000 European homes. Paiano et al. (2013) examined the sustainability of the mobile phone by its energy consumption and the authors concluded that the entire mobile phone system consumes approximately $2200 \mathrm{GWh}$ per year, which is equal to $0.7 \%$ of the national electricity consumption, and produces potential e-waste from end-of-life devices totaling over 11 thousand tones for the period from 2007 to 2012. Vergara et al. (2014) argued that reducing the energy consumption of wireless transmissions begins by being aware of the energy consumption characteristics of different technologies such as $3 \mathrm{G}$ and WiFi. Snowden (2005) stated that the energy consumption of mobile phone batteries contributes significantly to the device's environmental impact. The main impact associated with day to day mobile phone use is the power used during the charging process, and the charger represents about $7 \%$ of the life-time energy consumption of a typical mobile phone (Nokia, 2006). Most consumers are not aware of the effect of mobile phones on $\mathrm{CO}_{2}$ production and its emissions are expected to raise 55 million metric tons due to the increase in mobile communications by 2020 (Soonenschein et al, 2009).

\subsection{Environment Risks}

Mobile or Cell phones are fabricated with heavy metals such as cadmium, lead, lithium, mercury and brominated flame retardants, which are used in the parts of printed circuit board (PCB), liquid crystal display (LCD), keypad, plastic casing, batteries and chargers. These substances cause severe environmental collision due to their levels of toxicity. Replacing the handsets every year, as new models become available every year, creates an unnecessary carbon footprint and hazardous waste. Robinson (2009) stated that improper disposal of waste mobile phones caused significant health effects and environmental degradation in the developing world. Mobile recycled wastes led to contamination of the soil, water, fish, and wildlife. For example, the leakage of cadmium in the battery from a single phone could contaminate 600,000 liters of water. Deloitte (2010) identified the absence of proper recycles and reuses program causing more than 7,000 tons of toxic cell phone components (i.e. more than 80 percent hazardous) to be dumped in landfills by 2012 . The resulting contamination will leave far-reaching consequences to be faced by the environment and all the living forms of the earth. Tóth et al. (2012) 
examined how mobile phones are used to gather environmental and health information for utilization. Unused parts of the cell phone are disposed in the environment affecting all the elements of the environment, i.e. fertility or geological structure of the land, human health, wildlife, sea and plant life (Bharodiya \& Kayasth, 2012). Semiprecious metals like copper is extracted when mobile phones are recycled casually, leading to the discharge of toxicants into groundwater below and the air above (Lim \& Schoenung, 2010). Lakshmi and Nagan (2010) reported that lead, a possible carcinogen can accumulate in the environment resulting in acute and chronic effects on microorganisms, plants, animals and humans, and the authors also noted when mercury makes its way into water it is transformed into methylated mercury and eventually ends up in food causing brain damage. Lithium has a high degree of chemical activity which by itself can pollute the water when exposed (Clean Up Mobile Phones, 2007). Thus, these substances may cause major crisis in the environmental by seeping from the decaying waste in landfills into ground water, contaminating the soil and eventually entering the food chain.

\subsection{Health Risks}

In regards to human health, the health hazards are associated with high-toxic substances released from the mobile phones. Cocosila (2007) investigated the effects of perceived health risks due to the usage of $3 \mathrm{G}$ mobile phones. Barnett et al. (2007) assessed the awareness of a precautionary advice contained within the Department of Health (DoH) leaflet about mobile phone health risks, and public responses to it. Lakshmi and Nagan (2010) stated that cadmium may cause lung and prostate cancer, and is toxic to the gastrointestinal tract, the kidneys, and the respiratory, cardiovascular and hormonal systems. Lead causes damage to the central and peripheral nervous systems, blood systems,

and kidneys. Brominated flame retardants may increase the cancer risk of digestive and lymph systems. Thomée et al. (2011) found that increase in the frequency of mobile phone usage was associated with sleep disturbances and symptoms of depression for men and women at 1-year follow-up. Kleef et al. (2010) studied the health concerns associated with acceptance of mobile phone technology. Scientific proof is available to explain that the radiations produced by mobile phones cause severe health injury by affecting the brain of the human being (Uddin \& Ferdous, 2010). Aghav (2014) notified that beyond any doubt the electromagnetic fields are harmful and its adverse effects on a human body depend upon the intensity of the cell phone frequency. Davis (2010) mentioned that the European Union sponsored REFLEX project 
have found significant evidence of DNA damage from signals from modern $3 \mathrm{G}$ phones, and also found that split samples of human sperm studied in six different national laboratories indicate poorer morphology, motility, and increased pathology in cell phone exposed samples. Acharya et al. (2013) observed that many students suffered from frequent headaches, neck pains, limb pains, back aches, and had signs of redness in their eyes and symptoms of ringing sensation in the ears or tinnitus in their ears due to continuous mobile usage on some days. Certain neurological symptoms occur due to the frequent use of mobile phones, such as depression, sadness, irritability and headaches, anxiety, loss of memory and lack of sleep. Mobile phone's electromagnetic radiations and listening to loud music will cause hearing defects. Besides, Davis (2013) has mentioned in his webpage that the exposure to radiation from cell phones may also play a vital role in the growing spate of serious problems including attention and hearing deficits, autism, behavioral changes, insomnia, tinnitus, Parkinson's disease, Alzheimer's disease and a broad array of nervous system disturbances. The conclusion arrived on the health risks associated with mobile phones reported by many researchers are given below:

Table 1 Health risks associated with mobile phones

\begin{tabular}{|c|c|c|}
\hline S.No. & Authors & Conclusions \\
\hline 1. & Khurana et al. (2009) & $\begin{array}{l}\text { Adequate epidemiologic evidence available to suggest } \\
\text { a link between prolonged cell phone usage and the } \\
\text { development of an ipsilateral or same sided brain tumor. }\end{array}$ \\
\hline 2. & Hardell et al. (2011) & $\begin{array}{l}\text { An increased risk of developing a type of brain tumor } \\
\text { (glioma) with the use of mobile or cordless phone. The } \\
\text { risk increased with latency time and cumulative use in } \\
\text { hours and was highest in subjects with first use before } \\
\text { the age of } 20 \text {. }\end{array}$ \\
\hline 3. & de Vocht et al. (2011) & $\begin{array}{l}\text { Identified a small but potentially significant rise in } \\
\text { temporal and frontal lobe brain tumors - the brain } \\
\text { regions which are highly exposed to mobile phone } \\
\text { radiation. }\end{array}$ \\
\hline 4. & Agarwal et al. (2009) & $\begin{array}{l}\text { RF electromagnetic waves emitted from cell phones } \\
\text { may lead to oxidative stress in human semen. We } \\
\text { speculate that keeping the cell phone in a trouser pocket } \\
\text { in talk mode may affect spermatozoa and impair male } \\
\text { fertility. }\end{array}$ \\
\hline 5. & Cardis et al. (2011) & $\begin{array}{l}\text { An increased risk of glioma in long-term mobile phone } \\
\text { users with high RF exposure and of similar, but } \\
\text { apparently much smaller risk in aquiring another type } \\
\text { of brain tumour (meningioma). }\end{array}$ \\
\hline
\end{tabular}


6. Carrubba et al. (2010)

Mobile phones trigger EP at the rate of $217 \mathrm{~Hz}$ during ordinary use. Chronic production of the changes in brain activity might be pertinent to the reports of health hazards among mobile phone users.

7. Divan et al. (2012) Cell phone use was associated with behavioral problems at 7 years of age, and this association was not limited to early users of the technology.

8. $\quad$ Kesari et al. (2011) RF electromagnetic wave from commercially available cell phones might affect the fertilizing function of spermatozoa.

9. Kundi et al. (2011) It cannot be dismissed from the data presented that the increase in temporal lobe malignant brain tumors (and maybe to some degree also frontal lobe tumors) is partly due to mobile phone use.

10. Kwon et al. (2011) Short-term mobile phone exposure can locally suppress brain energy metabolism.

11. Levis et al. (2011) The results from meta-analyses showed an almost doubling of the risk of brain tumours induced by long-term mobile phone use or latency.

12. Meo et al. (2010) Long-term exposure to mobile phone radiation leads to reduction in serum testosterone levels in Wistar albino rats. Testosterone is a primary male gender hormone, and any change in the normal levels may be devastating for reproductive and general health.

13. Morgan et al. (2009) Cell phones shown to cause brain tumors have potentially high public health impact.

14. Panda et al. (2010) Long-term and intensive mobile phone use may cause inner ear damage.

15. Salama et al. (2010) The pulsed RF emitted by a conventional mobile phone which was kept on a standby position, could affect the sexual behavior in the rabbit.

Aghav (2014) alarmed that most of the people were unaware about health hazard of continuous emission of radiation. Today, there is an upsurge of public concern about the possible health hazards of this new technology. The impacts of mobile phone radiation on human health have come into focus of the researchers (Anvari et al., 2013).

Apart from the health risks of mobile phone's radiation, this article also brings to light the mobile phones-related road accidents. The use of mobile phones by vehicle drivers and pedestrians will cause road accidents due to their loss of concentration. Driving while talking, texting, or using the internet distracts drivers and increases the risk of accidents. Teenagers are at the greatest risk to become victims of accidents due to cell-phone use while 
driving. Almost 9 in 10 teenage drivers admit to engaging in distracted driving behaviors, such as texting or talking on a cell phone. Acharya et al. (2013) emphasized that accident due to cell-phone use while driving is commonly seen on the roads today. Khan et al. (2008) confirmed that $36 \%$ of road accidents are due to the use of mobile phones while driving a vehicle. Karger (2005) also verified using a mobile phone while driving a car is significantly associated with a higher risk of vehicle collisions. Mobile phones are the commonest hand-held device with harmful effects. Therefore, it is necessary to conduct research on sustainability for defeating those issues.

\section{Material and Methods}

All the information and data presented in this paper were gathered from various sources of secondary data. The sources are online databases like ProQuest, Emerald, Ebsco and ScienceDirect. The online search database provided secondary data such as journals and extracts from newspapers, books and magazines. Some of the information and data were obtained from the internet search engines like Google. The research framework was developed as shown in Figure 2.

\section{Result and Discussion}

To reduce the environmental and health risks of mobile phones, this study identified the perspectives on sustainability such as design, manufacture, energy consumption, recycling, reusing and take back to mitigate and minimize the negative impacts of mobile phones. Although some action can be taken to mitigate these impacts, EITO (2002) also confirmed that the design, manufacture, operation and disposal of information communication technology (ICT), have an overall negative impact on the environment. The control remedies are discussed below:

\subsection{Designing and Manufacturing of Mobile Phones}

Mobile phones are becoming more energy-efficient and are eliminating the use of hazardous materials. Nokia (2012) suggested the integration of the concept of 'Design for the Environment' into product and technology development, and sound end-of-life practices. During product creation, they focus on energy efficiency, sustainability on the use of materials, smart packaging, and creating environmental services. This may engage people to adopt more sustainable 


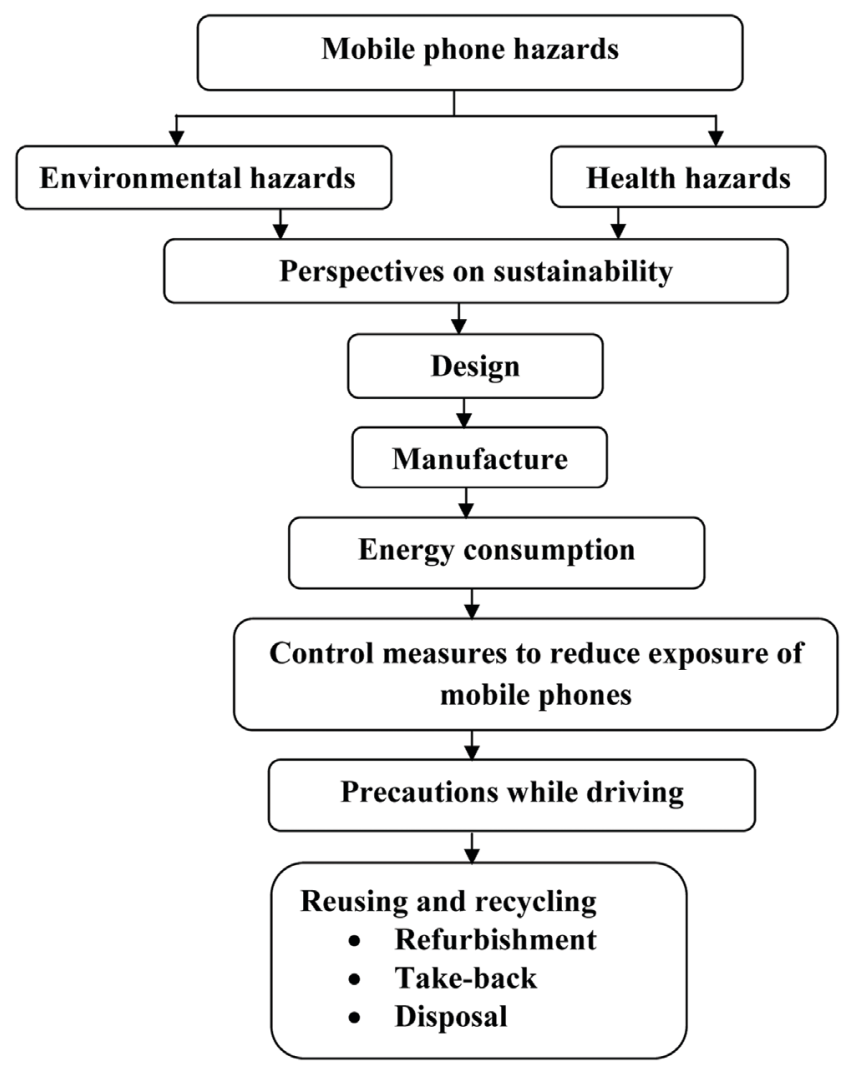

Figure 2 Research framework.

lifestyles. Environment specialist who supports the product development project should be dedicated for development of new products. They verify the implementation of legal environmental requirements and voluntary substance and materials' requirements, promote the implementation of most sustainable alternatives for material choices and energy efficiency, and provide sustainability reporting like 'Eco Profiles'. Bharodiya and Kayasth (2012) implied that the cell phone manufacturing companies have to minimize the use of hazardous metals and materials those harm the environment or may choose for those that are eco friendly. The manufacturers have to use recyclable metals and materials without emission of carbon dioxide so that there is minimum disposal on the earth. The manufacturers of cell phone have to appoint authorized distributors to sell cell phones, and the information about the authorized distributorship should be maintained by the government of 
respective nations. If any persons or organizations found to sell cell phones illegally without authorization from the manufacturers, strict actions should be taken. Authorized distributors should provide detailed notes about the impacts of cell phone on environment along with the user manual booklet. The government should strictly compel to follow all the policies and rules shown. If any manufacturer, distributor and customer found guilty then, appropriate fine in terms of money and/or imprisonment and, cancellation of the license may be carried out. Government can add this additional duty on the Ministry of environment to minimize or remove the impacts of cell phone on the environment. Groupe Speciale Mobile Association (2012) suggested ideal solution, from an environmental perspective, is to design a mobile phone with reuse, recycling and minimal disposal in mind. This starts with reducing energy input to the manufacture of components, substituting fewer hazardous substances (for example, the use of lead-free solder), and minimizing mixing of materials, such as metals embedded in plastics, which could be difficult to separate during recycling. Designing a phone for easy dismantling is also an important factor, as this would reduce the cost of refurbishment and recycling.

However, while the list of handset functions grows, the actual product size decreases. This produces environmental benefits through reduction in the use natural resources during manufacture, and the substitution of one device for many. Motorola is currently evaluating the use of biodegradable plastics in mobile phone covers with a view to using composting in their disposal. In order to further reduce environmental impacts, NTTDoCoMo has announced the use of recycled plastics in its new phone accessories, and Fujitsu is developing a plastic derived from corn starch. The mobile industry's pioneering switch to batteries with a higher-energy density has also produced environmental benefits. For example, power cells currently in use require fewer resources during manufacture, and avoid the use of toxic metals such as lead and cadmium. This makes the batteries much safer during the recycling and disposal processes. Mobile devices should be equipped with multiple functionalities, for instance; many include a digital camera, music player, navigation, web browser and several other features (all in one product) to help consumers reduce their own environmental footprint and avoid buying, using and charging several separate devices, when one device can be used for many different purposes.

An Integrated Product Policy project has been established to identify the improvement options that Nokia and the stakeholders could take to enhance the environmental performance of the phones. Nokia introduced the Green 
Channel store, which has information about applications and services related to the environment, to raise public awareness about sustainable lifestyles, health and well-being, and social responsibility. Vodafone (2013) aimed to reduce the environmental impacts of mobile phone products and services through measures designed to empower customers to make more sustainable choices. Measures such as Eco-rating scheme launched by Vodafone, assesses the handsets on a scale between 1 and 5, with 5 being the most ethical and environmentally responsible. Manufacturers are asked to respond to more than 200 questions covering the environmental and social impacts of each phone across its lifecycle, from the mining of raw materials used to make components to consumer use and disposal, and the level of commitment of the manufacturer to managing its own impacts. This assessment is carried out annually. Vodafone concentrates on working with operators, manufacturers, suppliers, the GSMA (Groupe Spéciale Mobile Association) and the ITU (International Telecommunication Union) to develop an industry standard for measuring the environmental and social impact of mobile phones and other devices. Vodafone works with both their suppliers and customers to reduce the impacts of their products across their lifecycle. The suppliers aim to improve their sustainability of the performance by sourcing raw materials and manufacturing products thereby empowering customers to make more sustainable choices and also helping customers to achieve their sustainability goals through low carbon solutions.

\subsection{Energy Consumption}

In order to satisfy consumer expectations about talk and standby time, there have been significant improvements in the energy efficiency of mobile phones. Over the last 20 years, the standby operating time of a mobile phone on a single battery charge has increased from around 4 hours to up to 12 days or more, while the size of batteries has been greatly reduced. Industries have also been focusing on reducing the phone's power consumption during the charging period. However, consumers can also make an important environmental difference by simply switching off the phone and charger whenever possible. This has been accomplished through changes in battery chemistry and reductions in the overall energy requirements of the circuitry in mobile phone (Groupe Speciale Mobile Association, 2012). Vodafone is a signatory to the GSMA's industry-wide commitment to introduce a universal charger. This initiative aims to reduce electronic waste by eliminating the need for consumers to replace their charger when they buy a new phone. Vodafone 
also offered solar-powered charging solutions that can reduce environmental impacts from charging phones and extend access to reliable, renewable-energy supplies in remote areas of emerging markets. Vodafone helps consumers to make an informed choice about which mobile phone they would like to buy in order to reduce impacts from charging their phone and to recycle it when they no longer use it. For instance, Nokia estimates that if just 10\% of the world's mobile phone users turned off their chargers after use, the energy saved in one year could be power 60,000 European homes. Zadok and Riikka (2010) have provided the Green Switch methodology that can be adapted to achieving positive environmental impacts; for instance, battery life increase through usage of Green Mode to reduce energy consumption during recharge of the mobile device. Nokia (2005) proposed these options for improvements in mobile phones: optimization of life-span; reduction in energy consumption and environment friendly chemicals used during component manufacture; influencing the buying, usage and disposal patterns of consumers; end-of-life, management of disposed mobile phones; reduction of energy consumption of network infrastructure; development of suitable environmental assessment methods; and development of a conducive policy environment. Hu and Kaabouch (2012) indicated that Wi-Fi consumes much less energy compared to a $3 \mathrm{G}$ network and using Wi-Fi as much as possible is the key to achieving more energy-efficient smartphones. Fishbein (2002) implied that mobile devices should be based on other resources, which are zincair technology, solar power, and muscle power in order to back up recharges rather than substitutes for batteries and adapters, and users don't need to wait for the phone to recharge.

\subsection{Control Measures to Reduce Exposure of Mobile Phones}

Better Health Channel (2013) suggested the following measures to reduce exposure of mobile phones:

- Choosing a mobile phone model that has a low specific absorption rate (SAR), that refers to the amount of radio frequency (RF) radiations absorbed by body tissues.

- Using a landline phone if one is available.

- Keeping your mobile phone calls short.

- Using a hands-free kit.

- Not carrying your mobile phone close to your body when it is switched on. 
- Being wary of claims that protective devices or 'shields' can reduce your exposure to radio frequency (RF) radiation.

Davis (2011) also provided the following hidden safety warnings in using mobile devices:

- Don't hold a cell phone directly up to your head. Use a headset or speakerphone to talk on the phone.

- Pregnant women should keep cell phones away from their abdomen and men who wish to become fathers should never keep phones on in their pocket.

- Don't allow children to play with or use your cellphone. Older children should use a headset when talking on a cell phone.

- Turn off your wireless router at night to minimize exposure to radiation.

- Eat green vegetables and get a good night's sleep in a dark room to enhance natural repair of DNA that may have been damaged by radiation.

\subsection{Precautions while Driving}

For avoiding road accidents while attending to mobile phone calls, the study identified some well-being precautions for avoiding vehicle collisions. They are as follows:

- During any emergency call, stop the vehicle and then attend the call.

- Slowed the vehicle down.

- Choose a time when there was little traffic.

- Choose a time when the traffic was still or moved slowly.

Chauhan (2002) recommended the following safety measures for attending phone calls while driving a car:

- Shorter conversation will help to reduce the duration of exposure.

- Calls can be planned in such a way that longer conversations be made using ordinary land line phones.

- Minimize the conversation inside the car because the reflection from the car cavity may amplify the radiation. If this cannot be avoided the use of roof antenna would help. Use of plug-in earpiece will separate antenna further away from body/head.

\subsection{Reusing and Recycling}

According to the Basel Convention and the Mobile Phone Partnership Initiative (MPPI) guidance document published in November 2006, "Re-use, 
directly or via repair or refurbishment is usually the preferable option over recycling and disposal from an environmental perspective. Re- use can extend product life and means less environmentally damaging extraction, less energy consumption and less waste. Re-use of second-hand equipment can also often mean a lower price for products, thus increasing accessibility for more people who might not otherwise be able to afford the product". The energy and raw materials used to produce millions of new mobile phones contributes to $\mathrm{CO}_{2}$ emissions and global warming. Mobile phones can be separated into their different components and recycled. For example, the copper, gold, lead, cadmium, silver and nickel; the gold and silver recovered can be made into jewelry. Often the batteries are first separated from the mobile phone and sorted into their various types before reprocessing by specialist recyclers. Nickel cadmium, nickel-metal hydride and lithium ion/polymer batteries have their metals recovered and reused in products such as power tools, saucepans and new batteries. The metals extracted during this process including gold, platinum, palladium and silver are put back into productive use. Phones deemed to be beyond repair or simply too old still have a residual value, and their parts may be reused. Therefore, practical and environmentally responsible methods for the recycling of end-of-life phones have to be developed in conjunction with those for electronic equipment. Groupe Speciale Mobile Association (2012) suggested that phones may be further dismantled and some parts shredded, or processed intact for material and energy recovery. Chargers, accessories and even packaging should be recycled. It is generally not economic to reuse the plastic components due to mixed grades, and the presence of dyes and other contaminants, so energy is recovered through the incineration process. In one case, energy produced from the incineration of waste materials is used to heat a village local to the recycling plant. In another, plastics are shredded and used locally in the manufacture of fence posts and pallets. The handsets, batteries, plastics and accessories may be separated according to their chemical and material composition; plastics can be recycled to make items such as traffic cones and metals are used again as good-quality raw materials. If a mobile phone is returned by a consumer and sent to a company where it may be refurbished, then it may be sold for reuse. This may not be the case if the mobile phones are not properly recycled when they reach the it end-of-life. Mobile phones have a greater chance of being reused if they are donated quickly rather than being stored. Importantly, when questioned, very few people reported that they would just throw the old phone away. 
One way of reducing the negative environmental impact of smart phones is to have them recycled at the end of their lives cycle (Silveira and Chang, 2010). Vodafone (2013) encouraged customers to return their unwanted handsets and accessories to them for reuse (whenever possible) and recycling. Vodafones are also to raising awareness about their recycling programs through posters, leaflets, in-store collection points and prepaid envelopes with new handsets. Vodafone offers a buyback proactive procedure, which aims to increase the number of handsets collected for recycling, but this also has a significant commercial benefit for Vodafone. Vodafone also offers incentives for customers to keep their handsets for longer, for instance, by offering SIM-only price plans with a lower monthly subscription rate for customers who continue using their existing phone rather than upgrading. Nokia (2012) proposed that recycling programs targeted the removal of valuable materials that can be used for new products. Nokia build recycling programs by identifying safe and reliable recyclers, developing the infrastructure for reverse logistics, offering a variety of their own take-back options, and partnering with others to increase capacity to take back old mobile devices that might otherwise be headed for landfill. The research also found that used mobile phones were particularly important to people who were new to mobile telephony, those on low incomes, those under the age of 18, manual workers and non-workers. These users of used mobile phones were generally as happy with their device as users of new phones.

\subsubsection{Refurbishment}

Mobile phones are wiped of data, physically repaired, repackaged with new instructions and sent to suppliers. According to Groupe Speciale Mobile Association (2012), some refurbishing companies have sought environmental accreditation for proper management of the entire process. For a mobile network operator choosing a recycling partner, assurances that a partner operates good practices and, with transparency in the way they work are important. For responsible partnering companies, environmental management systems are often used to provide assurance about the proper treatment of collected phones. Collected phones must first be evaluated to determine those that are most likely to be suitable for reuse. These phones will then be subjected to a series of tests to determine suitability for reuse with or without further repair. The testing equipment and procedures are similar to those in manufacturer repair centers. Faulty parts will be replaced; batteries evaluated or exchanged, and the phone's appearance reconditioned. Particular 
care is needed to ensure that replacement batteries have proper internal safety circuits. All original customer information is securely erased, and the refurbished phone must meet all regulatory requirements. These steps are labor-intensive and in some cases the work is done in lower cost economies using internationally accepted health and environmental controls. Finally, the refurbished phone will be packaged for resale along with a battery, charger, and instructions. Any residual materials arising during the refurbishment process are disposed of in an environmentally sound manner. The price of a refurbished phone will vary significantly, depending upon the model type, its age and appearance. The extent of any guarantee offered by the refurbisher is another key factor. Indicative prices for one scheme are in the range of US\$30-40. Mobile manufacturers incorporate measures such as material identification and easy disassembly, to make recycling easier. Many people are looking for simple phones, so when upgrading, the user may be able to find a potential user for their old phone. The user can also be a smart consumer and think twice before upgrading their mobile phone; old phone still does the job, and the cost of a new one can be saved. Nokia has actively participated in the recast of the Waste Electrical and Electronic Equipment (WEEE), that has been made to establish and develop the existing national collection networks in every country, and these networks collect and treat all electronic waste from households. This represents a big step forward to making e-waste recycling the rule, not the exception. In addition, Nokia has participated in the development of legislation concerning e-waste in countries around the world, including India, China, Kenya, Mexico and Thailand during 2011 just to name a few. Nokia takes part in collective recycling schemes with other equipment manufacturers in Europe, Canada and Australia. Nokia also engages in programs raising local recycling awareness with retailers, operators, other manufacturers and authorities around the world. Nokia's take-back and recycling programs continue to expand into new markets, ensuring mobile devices to end up in an environment safe for recycling processes.

\subsubsection{Take-back}

Groupe Speciale Mobile Association (2012) noted that since the 1990s, the mobile communications industry had been working in cross-sector partnerships to deliver sustainable initiatives, including used mobile phone take-back schemes that often predate national and international legislation. The industry supports handset, battery and accessory take-back in more than 40 countries. In addition, several mobile phone manufacturers have processes in place to deal 
with phones returned through the repair or retail outlets. In most cases, takeback schemes were established as voluntary initiatives, with self-sustaining financial structures. With some, a proportion of the revenues earned by take-back schemes are reinvested in environmental and charitable initiatives, depending on the customer culture in the individual countries. The typical price range for unsorted, used phones is in the range US\$1-10. Collection and recycling programs are operated and financed by the equipment producers, while municipal collections, specified waste management sites and shops selling equipment are the main collection sites.

Experience from network operators indicate that one of the most important steps in establishing a successful take-back scheme is the incentive provided to customers. These vary depending on customers and cultural preferences but generally involve donations to charity, extra call minutes for the customer or a discount on a different phone. Nokia works to make sure consumers are aware of the channels open to them for take-back and recycling and support all safe and effective methods of mobile phone recycling. Success on take-back and recycling can be measured in three ways: the number of countries covered, the number of people reached with the recycling message in dedicated campaigns, and the weight of mobile devices and accessories recycled.

\subsubsection{Disposal}

If a mobile phone cannot be refurbished or if the components cannot be reused or recycled, the remaining materials are sent to an environment sound for disposal. Groupe Speciale Mobile Association (2012) reported that the remaining materials can be made insoluble at high-temperature processing so that they will not leach toxic substances into the environment, and may be safely used as a construction aggregate. In an efficient take-back program, only a tiny proportion of the materials that make up mobile phones should go for disposal (less than 10\%). Consumers should be encouraged not to throw away their mobile phones with household rubbish, as the phones may end up in a landfill site. Instead, they should be deposited in a take-back scheme for refurbishment or recycling. Murphy (2008) suggested that proper disposal of old cell phones by users should involve taking it to a place that recycles cell phones or to one that will ship it off for reuse. Some companies have a take-back program and will accept the old phone when a new one is purchased from them, and also by using the old phone for a few more years you can keep it out of the cycle of waste. Bharodiya and Kayasth (2012) provided that every manufacturer has to recycle minimum $70 \%$ of metals, those used to produce the new cell phone so that only $30 \%$ of materials disposed into the environment. 
Government should reserve one place to dispose, which is farthest from city to dispose the unrecyclable and hazardous parts of cell phone.

\section{Conclusions}

From the above discussions, sustainable strategies are needed in guiding and developing proactive customer intentions to use mobile phones with minimum risks to health and the environment. While developing awareness among customers in using mobile phones so as to minimize risks, manufacturers should develop safe measures with greenery quotes that would influence customer buying behavior and customer retention of mobiles. Companies should find and refine best sustainable solutions in improving service quality and developing the trust of users in regards to the risks caused by the use of mobile phones. The study suggested that both governments and the mobile industry should accomplish to upgrade effective regulations and legislation aspects for design, manufacture, energy consumption, recycling and reuse of mobile phones so as to mitigate and reduce the different harmful impacts.

There are a few limitations to this study, firstly, knowledge of mobile phone hazards is still accumulating, and the literature on this subject is quite limited. Secondly, this research has been conducted with secondary data, with the main aim to obtain a clear conceptual picture of the relevant problems and solution directions. However, it would be good to conduct future research using primary data on producer and consumer behaviors, perspectives and strategies to get more definite insight into mobile phone hazards and solutions to these.

\section{References}

[1] Acharya, J. P., Acharya, I., and Waghrey, D. (2013). A study on some of the common health effects of cell-phones amongst college students. J. Commun. Health Edu. 3, 1-4. doi: NODOI PMID:NOPMID

[2] Agarwal, A., Desai, N. R., Makker, K., Varghese, A., Mouradi, R., Sabanegh, E., et al. (2009). Effects of radiofrequency electromagnetic waves (RF-EMW) from cellular phones on human ejaculated semen: an in vitro pilot study. Fertil. Steril. 92, 1318-1325. doi: 10.1016/j.fertnstert.2008.08.022 PMID:18804757

[3] Aghav, S. D. (2014). Study of radiation exposure due to mobile towers and mobile phones. Ind. Streams Res. J. 3, 1-6. doi: NODOI PMID:NOPMID 
[4] Anvari, M. M., Oliya, A., Mahdeloe, S., Harbi, T. F., Masih, M., and Bagheri, H. (2013). Environmental impacts of electromagnetic waves of mobile phones on human health. Ann. Biol. Res. 4, 80-84. doi: NODOI PMID:NOPMID

[5] Barnett, J., Timotijevic, L., Shepherd, R., and Senior, V. (2007). Public responses to precautionary information from the Department of Health (UK) about possible health risks from mobile phones. Health Policy 82, 240-250. doi: 10.1016/j.healthpol.2006.10.002 PMID:17113180

[6] Bereketli, İ., Genevois, M. E., and Ulukan, H. Z. (2009). Green Product Design for Mobile Phones. Int. Sch. Sci. Res. Innov. 3, 211-215. doi: NODOI PMID:17566446

[7] Better Health Channel. (2013). Mobile Phones and your Health. Available at: http://www.betterhealth.vic.gov.au/bhcv2/bhcarticles.nsf/pages/ Mobile_phones_and_your_health [accessed January 10, 2014].

[8] Bharodiya, A. K., and Kayasth, M. M. (2012). Impact of cell phones' life cycle on human and environment: challenges and recommendations. J. Environ. Res. Dev. 7, 530-536. doi: NODOI PMID:NOPMID

[9] Cardis, E., Armstrong, B. K., Bowman, J. D., Giles, G. G., Hours, M., and Krewski, D. (2011). Risk of brain tumours In relation to estimated RF dose from mobile phones-results from five Interphone Countries. Occup. Environ. Med. 68, 631-640. doi: 10.1136/oemed-2011-100155 PMID:21659469

[10] Carrubba, S., Frilot, C. II, Chesson, A. L. Jr., and Marino, A. A. (2010). Mobile-phone pulse triggers evoked potentials. Neurosci. Lett. 469, 164-168. doi: 10.1016/j.neulet.2009.11.068 PMID:19961898

[11] Chauhan, S. (2002). Environmental and Health Hazards of Mobile Devices and Wireless Communication. CSE 6392 - Mobile Computer Systems Paper Series. Available at: http://crystal.uta.edu/ kumar/cse 6392/termpapers/Savita_paper.pdf [accessed June 01, 2014].

[12] Clean Up Mobile Phones - Additional Information Sheet. (2007). Mobile Phones and the Environment. [accessed May 21, 2014] Available at: http://www.cleanup.org.au/PDF/au/additional-info-sheet_mobilephonesthe-environment.pdf

[13] Cocosila, M., Turel, O., Archer, N., and Yuan, Y. (2007). Perceived health risks of $3 \mathrm{~g}$ cell phones: do users care? Commun. ACM 50, 89-92. doi: 10.1145/1247001.1247026 PMID:NOPMID

[14] Davis, D. (2010). Cell Phones: a new environmental hazard that can be reduced. Physicians for Social Responsibility, Receipt of the 1985 
Nobel Prize for Peace. Available at: http://www.psr.org/environmentand-health/environmental-health-policy-institute/responses/cell-phonesa-new-environmental-hazard-that-can-be-reduced.html [accessed June 01, 2014].

[15] Davis, D. (2013). Cell Phones, Radiation and Your Child's Health. Available at: http://healthychild.org/cell-phones-radiation-your-childs-health/ [accessed June 01, 2014].

[16] de Vocht, F., Burstyn, I., and Cherrie, J. W. (2011). Time trends (19982007 ) in brain cancer incidencerates in relation to mobile phone use in England. Bioelectromagnetics 32, 334-339. doi: 10.1002/bem.20678 PMID:NOPMID

[17] Deloitte. (2010). Cell Phones - Need to Better Manage Growing Cell Phone Waste. Available at: https://www.deloitte.com/assets/DcomCostaRica/Local\%20Assets/Documents/Servicios/RCS/100830-cr_RCS _Green_phone.pdf [accessed May 20, 2014].

[18] Divan, H. A., Kheifets, L., Obel, C., and Olsen, J. (2012). Cell phone use and behavioural problems in young children. J. Epidemiol Commun. Health 66, 524-529. doi: 10.1136/jech.2010.115402 PMID:21138897

[19] Environment and Human Health, Inc. (2012). The Cell Phone Problem: Technology, Exposures and Health effects. Available at: http:// www.ehhi.org/reports/cellphones/cell_phonereport_EHHI_Feb2012.pdf [accessed June 03, 2014].

[20] Fishbein, B. K. (2002). Waste in the Wireless World: The Challenge of Cell Phones. Inform, Strategies for Better Environment. Available at: http://informinc.org/reportpdfs/wp/WasteintheWirelessWorld.pdf [accessed May 25, 2014].

[21] Gsm Association. (2012). Environmental Impact of Mobile Communications Devices. Available at: http://www.gsma.com/publicpolicy/ wp-content/uploads/2012/03/environmobiledevices.pdf [accessed May 21, 2014].

[22] Hardell, L., Carlberg, M., and Hansson, M. K. (2011). Pooled analysis of case-control studies on malignant brain tumours and the use of mobile and cordless phones including living and deceased subjects. Int. J. Oncol. 38, 1465-1474. doi: 10.3892/ijo.2011.947 PMID:21331446

[23] Hu, W. C., and Kaabouch, N. (2012). "Sustainable ICTs and management systems for green computing," in Mitigating the Environmental Impact of Smartphones with Device Reuse, Chap. 11, eds X. Li, P. Ortiz, B. Kuczenski, D. Franklin, F. T. Chong. Available at: http://www. cs.ucsb.edu/ xun/papers/reuse-ictbook12.pdf [accessed May 25, 2014]. 
[24] Kang, D. H. P., Chen, M., and Ogunseitan, O. A. (2013). Potential environmental and human health impacts of rechargeable lithium batteries in electronic waste. Environ. Sci. Technol. 47, 5495-5503. doi: 10.1021/es400614y PMID:23638841

[25] Karger, C. P. (2005). Mobile phones and health: a literature overview. J. Med. Phys. 15, 3-85. doi: NODOI PMID:NOPMID

[26] Kesari, K. K., Kumar, S., and Behari, J. (2011). Effects of radiofrequency electromagnetic wave exposure from cellular phones on the reproductive pattern in male Wistar rats. Appl. Biochem. Biotechnol. 164, 546-559. doi: 10.1007/s12010-010-9156-0 PMID:21240569

[27] Khan, A. R., Zaman, N., and Muzafar, S. (2008). Health hazards linked to using mobile cellular phones. J. Inform. Commun. Technol. 2, 101-108. doi: NODOI PMID:NOPMID

[28] Khurana, V. G., Teo, C., Kundi, M., Hardell, L., and Carlberg, M. (2009). Cell phones and brain tumors: a review including the long-term epidemiologic data. Surgical Neurol. 72, 205-214. doi: 10.1016/j.surneu.2009.01.019 PMID:19328536

[29] Kick the Habit. (2008). A UN Guide to Climate Neutrality. United Nations Environment Programme. Available at: http://www.grida.no/files/publi cations/kick-the-habit/kick_full_lr.pdf [accessed June 09, 2014].

[30] Kleef, E. V., Fischer, A. R. H., Khan, M., and Frewer, L. J. (2010). Risk and benefit perceptions of mobile phone and base station technology in Bangladesh. Risk Anal. 30, 1002-1015. doi: 10.1111/j.15396924.2010.01386.x PMID:20409037

[31] Kundi, M. (2011). "Comments on de Vocht et al. Time trends (19982007 ) in brain cancer incidence rates in relation to mobile phone use in England. Bioelectromagnetics 32, 673-674. doi: 10.1002/bem.20679 PMID:NOPMID

[32] Kwon, M. S., Vorobyev, V., Kännälä, S., Laine, M., Rinne, J. O., Toivonen, T., et al. (2011). GSM mobile phone radiation suppresses brain glucose etabolism. J. Cerebral Blood Flow Metabol. 31, 2293-2301. doi: 10.1038/jcbfm.2011.128 PMID:21915135

[33] Lakshmi, R., and Nagan, S. (2010). Studies on concrete containing E plastic waste. Int. J. Environ. Sci. 1, 282-295. doi: NODOI PMID:NOPMID

[34] Levis, A. G., Minicuci, N., Ricci, P., Gennaro, V., and Garbisa, S. (2011). Mobile phones and head tumours. The discrepancies in cause-effect relationships in the epidemiological studies - how do they arise? Environ. Health 10, 1-15. doi: 10.1186/1476-069X-10-59 PMID:21679472 
[35] Lim, S. E., and Schoenung, J. M. (2010). Toxicity potentials from waste cellular phones, and a waste management policy integrating consumer, corporate, and government responsibilities. Waste Manag. 30, 1653-1660. doi: 10.1016/j.wasman.2010.04.005 PMID:20418088

[36] Lincoln, J. D., Ogunseitan, O. A., Shapiro, A. A., and Saphores, J.-D. M. (2007). Leaching assessments of hazardous materials in cellular telephones. Environ. Sci. Technol. 41, 2572-2578. doi: 10.1021/es0610479 PMID: 17438818

[37] Meo, S. A., Al-Drees, A. M., Husain, S., Khan, M. M., and Imran, M. B. (2010). Effects of mobile phone radiation on serum testosterone in Wistar albino rats. Saudi Med. J. 31, 869-873. doi: NODOI PMID:20714683

[38] Morgan, L. L. (2009). Estimating the risk of brain tumors from cellphone use: Published case-control Studies. Pathophysiology 2, 137-147. doi: 10.1016/j.pathophys.2009.01.009 PMID:19356911

[39] Murphy, M. (2008). Are Cell Phones Hurting the Environment? Available at: http://voices.yahoo.com/are-cell-phones-hurting-environment794299.html [accessed January 13, 2014].

[40] Nokia. (2005). Integrated Product Policy Pilot Project Stage I Final Report: Life Cycle Environmental Issues of Mobile Phones. Available at: http://ec.europa.eu/environment/ipp/pdf/nokia_mobile_05_04.pdf [accessed January 03, 2014].

[41] Nokia. (2006). Integrated Product Policy Pilot on Mobile Phones Stage III Final Report: Evaluation of Options to Improve the LifeCycle Environmental Performance of Mobile Phones. Available at: http://ec.europa.eu/environment/ipp/pdf/report_02_08_06.pdf [accessed January 03, 2014].

[42] Nokia. (2012). Nokia Sustainability Report 2011. Available at: http://i.nokia.com/blob/view/-/1449730/data/2/-/nokia-sustainability-re port-2011-pdf.pdf [accessed January 13, 2014].

[43] Paiano, A., Lagioia, G., and Cataldo, A. (2013). A critical analysis of the sustainability of mobile phone use. Res. Conser. Recycling 73, 162-171. doi: 10.1016/j.resconrec.2013.02.008 PMID:NOPMID

[44] Panda, N. K., Jain, R., Bakshi, J., and Munjal, S. (2010). Audiologic disturbances in long-term mobile phone users. J. Otolaryngol. Head Neck Surg. 39, 5-11. doi: NODOI PMID:20122338

[45] Robinson, B. H. (2009). E-waste: An assessment of global production and environmental impacts. Sci. Total Environ. 408, 183-191. doi: 10.1016/j.scitotenv.2009.09.044 PMID:19846207 
[46] Salama, N., Kishimoto, T., Kanayama, H. O., and Kagawa, S. (2010). Effects of exposure to a mobile phone on sexual behavior in adult male rabbit: an observational study. Int. J. Impotence Res. 22, 127-133. doi: 10.1038/ijir.2009.57 PMID:19940851

[47] Savvilotidou, V., Hahladakis, J. N., and Gidarakos, E. (2014). Determination of toxic metals in discarded Liquid Crystal Displays (LCDs). Res. Conserv. Recycling 92, 108-115. doi: 10.1016/j.resconrec.2014.09.002 PMID:NOPMID

[48] Silveira, G. T. R., and Chang, S.-Y. (2010). Cell phone recycling experiences in the United States and potential recycling options in Brazil. Waste Manag. 30, 2278-2291. doi: 10.1016/j.wasman.2010.05.011 PMID:20554440

[49] Snowden, K. (2005). "Product design in Electronic and Electrical Engineering - mobile phones," in Engineering for Sustainable Development Guiding Principles, 1st Edn, eds R. Dodds and R. Venables (Westminster: The Royal Academy of Engineering).

[50] Soonenschein, M., Grabowski, S., Stenger, J., and Haas, M. (2009). Why Go Green? A. T. KEARNEY, Inc.Marketing and Communications, Chicago, IL, U.S.A. Available at: https://www.atkearney.com/docu ments/10192/d3e4ca69-216c-4a0e-b028-29e3fe0a8c0b [accessed May 29, 2014].

[51] Thomée, S., Härenstam, A., and Hagberg, M. (2011). Mobile phone use and stress, sleep disturbances and symptoms of depression among young adults - a prospective cohort study. BMC Public Health 11, 1-11. doi: NODOI PMID:NOPMID

[52] Tóth, A. H., Kelemen, K., Piskóti, M., and Simay, A. E. (2012). Mobile Phones and Sustainable Consumption in China: An Empirical Study among Young Chinese Citizens. In: China - EU Cooperation for a Sustainable Economy. Corvinus University of Budapest, Budapest, 263-272. Available at: http://korny.uni-corvinus.hu/cneucoop_ fullpapers/s1/agneshofm2.pdf [accessed at: May 21, 2014].

[53] Uddin, A. S. M. I., and Ferdous, J. (2010). Radiation exposure of cell phones and its impact on human health - a case study in South Asia (Bangladesh) and some recommendations. J. Theor. Appl. Inform. Technol. 1, 95-97. doi: NODOI PMID:NOPMID

[54] Vergara, E. J., Tehrani, S. N., and Prihodko, M. (2014). EnergyBox: Disclosing the Wireless Transmission Energy Cost for Mobile Devices. Sustainable Computing: Informatics and Systems. Available at: 
http://www.ida.liu.se/labs/rtslab/publications/2014/VergaraNadjmTehra ni-EnergyBox.pdf. [accessed at: April 4, 2014].

[55] Vodafone. (2013). Vodafone Group Plc Sustainability report 2012/ 2013. Available at: http://www.vodafone.com/content/dam/sustainability/ pdfs/vodafone_sustainability_report_2012_13.pdf [accessed at: January $14,2014]$.

[56] World Commission on Environment and Development (Wced). (1987). Report of the World Commission on Environment and Development: Our Common Future. Available at: http://www.un-documents.net/wcedocf.htm. [accessed at: January 10, 2014].

[57] World Health Organization (Who). (2013). What are the health risks associated with mobile phones and their base stations? Available at: http://www.who.int/features/qa/30/en/ [accessed on January 10, 2014].

[58] Yu, J., Williams, E., and Ju, M. (2010). Analysis of material and energy consumption of mobile phones in China. Energy Policy 38, 4135-4141. doi: 10.1016/j.enpol.2010.03.041 PMID:NOPMID

[59] Zadok, G., and Riikka, P. (2010). The Green Switch: Designing for Sustainability in Mobile Computing. Paper presented at: The First USENIX conference on Sustainable information technology (SustainIT'10); February 22, 2010; USENIX Association Berkeley, CA, USA. Available at: http://static.usenix.org/event/sustainit10/tech/full_papers/zadok.pdf. [accessed at: January 12, 2014].

\section{Biography}

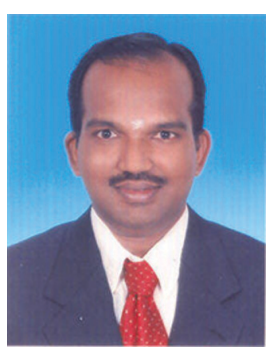

M. S. Velmurugan is a Research Scholar of information Technology and Management at the D.B. Jain College, University of Madras, India. His current research interests are on e-commerce, e-business, mobile phone, sustainable development and information technology related topics. 